\title{
Sledování formování odtoku na svazích Jizerských hor a Šumavy pomocí stopovacích experimentů, které jsou podkladem pro použití modelu MIPs
}

\author{
ALENA KULASOVÁ, ŠÁRKA BLAŽKOVÁ, LUKÁŠ VLČEK, BOHUMÍR JANSKÝ
}

Klíčová slova: MIPs - model odtoku ze svahu - pokusy se stopovači - odtokové procesy - sledování dráhy částic

\section{SOUHRN}

\begin{abstract}
Př́spěvek presentuje pokusy s umělým deštěm a stopovačem $v$ Jizerských horách, které jsou nezbytné pro modelování svahu modelem MIPs (Multiple Interacting Pathways [1]). Jsou podrobně popsány pokusy na několika svazích v povodí Lužické Nisy v Jizerských horách a na jednom svahu na Šumavě. MIPs je model založený na sledování dráhy částic. Cesty proudění jsou v něm popisovány pravděpodobnostně. Pracuje s částicemi (baličky vody) v různých cestách proudění definovaných rozdělením rychlostí a maticí prechodu, která representuje výměnu vody mezi jednotlivými cestami. Výstupy modelu MIPs byly predvedeny na experimentálním svahu na louce ve formě výpočtu scénáre postupného nasycování svahu při srážkových epizodách, zvláště první epizody po suchém období. V terénních pokusech je vidět rozdíl v procesech odtoku mezi lučním a zalesněným svahem. Přestože bylo stř́káno vysokými intenzitami i velkými objemy vody, na lesních svazích byl stále rozhodující vliv vysoké infiltrační kapacity v lese. Je tady zřejmý podstatný vliv preferenčních cest.
\end{abstract}

\section{ÚVOD}

Model MIPs byl vytvořen pro hornaté oblasti, ve kterých jsou infiltrační kapacity vysoké ve srovnání se srážkovými intenzitami a úhrny. Pokud půdní profil v těchto oblastech není nasycen vodou až do úrovně terénu, je povodňová odezva tvořena převážně podpovrchovým odtokem (tj. jedná se o mělkou podzemní vodu). Takové podmínky jsou časté zvláště na zalesněných svazích v mírném vlhkém klimatu s propustnými půdami a relativně př́krými svahy [2].

Pokud chceme porozumět geochemickým procesům $v$ povodích a jejich závislosti na hydrologii, je nutné, aby odtokový proces byl dobře popsán. Je třeba mít adekvátní představu o cestách proudění v terénu, kterou je obtížné získat třeba i jen pro jediný svah. Je také nutné mít hydrologický model, který toto proudění vhodně popisuje. Model MIPs [1,3] je pokusem o takové řešení. Cesty proudění $v$ terénu je zřejmě $v$ současnosti možno prozkoumat pouze $s$ využitím stopovačů. Nestači tedy mít k disposici jen hydrogram odtoku, protože z něj nelze zpětně soudit o podstatě procesů, které proběhly ve svahu nebo v povodí. Pro odtok z povodí mohou být rozhodující preferenční cesty [4-7], tj. obchvaty nebo zkratky, kterými voda obejde půdní matrici. Stopovače je možno použít v průběhu srážkoodtokové epizody jako v případě lokality Gardsjon [3]. To však předpokládá dlouhý výzkumný projekt. My jsme použili metodu experimentů skrápění části svahu vysokou intenzitou, kdy byl do vody prídáván stopovač $\mathrm{NaCl}$.

Procesy důležité pro tvorbu odezvy jsou $\vee$ nenasycené zóně: intenzita vstupu v úrovni terénu, změny vlhkosti půdy, rychlost fronty zvlhčení, hloubka hladiny podzemní vody, doba nutná k dosažení hladiny podzemní vody; v nasycené zóně: postupivost viny, vzdálenost od toku, doba nutná k dosažení toku. Cesty odtoku, kterými srážkový vstup prochází, závisí na struktuře a předcházející nasycenosti půdy. Srážková voda vstoupí do půdní matrice a teče svisle v závislosti na místních vodivostech a gradientech. Část vody může jít obchvaty a zkratkami a vyhnout se tak půdní matrici. Tyto preferenční cesty jsou spojeny s puklinami, kanálky po kořenech nebo jinými makropóry nebo se může jednat o oblasti vyšší propustnosti půdy. Preferenční cesty mohou mít rưznou hloubku, šířku, křivost a spojitost. Pro jednoduchost je možno predpokládat, že dominantní směr proudění v nenasycené zóně je svislý $[1,8]$.

Mnohočetné cesty proudění v nenasycené zóně jsou reprezentovány funkcí rozdělení svislých rychlostí, která závisí na hloubkách a časech vyplývajících ze vzájemného působení rozdělení vstupních intenzit a cest proudění v půdě, jež se mezi sebou také vzájemně ovlivňují [1].

Dále model pracuje $s$ rozdělením hloubek $\mathrm{k}$ hladině podzemní vody $v$ príslušných místech, které bude záviset na předcházejících podmínkách, odvodnění části svahu nad zkoumaným úsekem a tvaru svahu (rozbíhání nebo sbíhání proudnic). Z těchto údajů a rozdělení rychlostí můžeme dostat rozdělení dob dotoku $v$ nenasycené zóně. Výsledné rozdělení bude ve vzájemném vztahu k prostorovému rozdělení nasycených hydraulických vodivostí, z čehož získáme rozdělení dob dotoku v nasycené zóně. Ty budou v obecném prípadě záviset na dotaci z nenasycené zóny [1, 8].

Aby bylo možno smysluplně pracovat s modelem MIPs, je tedy třeba provést průzkum na vybraných svazích s využitím stopovačů.

Základní výzkumnou otázkou pro nás stejně jako pro více hydrologických týmů v Evropě a USA je bližší poznání procesů podpovrchového odtoku, který $\checkmark$ povodích $s$ vegetačním pokryvem, zejména zalesněných, tvoří většinu přímého odtoku při menších (častějších) povodních. Výzkum v tomto směru bude pokračovat v několika dalších letech.

Cílem tohoto příspěvku tedy je ukázat na př́ikladu typ výstupů z modelu MIPs a jeho využitelnost v Jizerských horách. K tomu bylo třeba vybrat, zř́idit a vystrojit pokusné svahy a provést pokusy se zkrápěním a stopovači. Jedná se o náš první článek v časopise k tomuto typu modelování a nutné experimentální části výzkumu. 


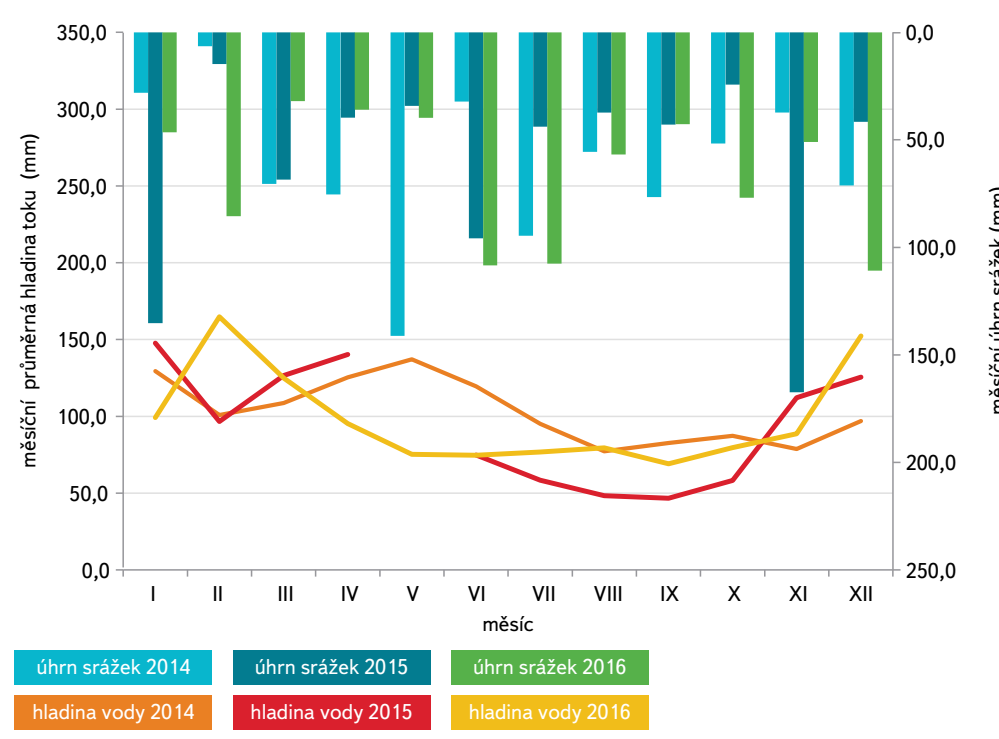

Obr. 1. Měsíční úhrny srážek a průměrné výšky hladiny vody ve stanici ČVUT v Dolních Lučanech v Jizerských horách 2014-2016

Fig. 1. Monthly precipitation totals and average water level depths in Czech Technical University station in Dolní Lučany in Jizera Mountains 2014-2016 (úhrn srážek - precipitation total; výška hladiny vody - water level depth; měsíční - monthly)

\section{Vysvětlení pojmů}

- MIPs (Multiple Interacting Pathways) - mnohočetné vzájemně se ovlivňující cesty odtoku

- Particle tracking - sledování dráhy cástic

- Random particle tracking - rychlosti částic jsou vzorkovány z náhodných rozdělení

- Bypassing - obchvat, zkrácení tzv. preferenčními cestami, část proudění se vyhne půdní matrici

- Tracing - použití stopovačů

- Transition probabilities - matice prechodu obsahující pravděpodobnosti výměny vody mezi jednotlivými cestami

— Tipping bucket - překlápěč pro měření objemů srážek nebo průtoku

- Conductivity - konduktivita - vodivost

\section{METODY}

\section{Model MIPs}

Prvním článkem o MIPs je príspěvek viz [1], inspirovaný pokusy se stopovači na Bear Brook ve státě Main [12]. V článku viz [5] je popsán případ transientního proudění experimentálním svahem v povodí Gardsjon ve Švédsku.

$\checkmark$ modelu MIPs jsou cesty proudění vody popisovány pravděpodobnostně $[1,13]$. Sledování drah částic, přičemž rychlosti jsou vzorkovány z náhodného rozdělení, pracuje s částicemi (balíčky) vody v rưzných cestách proudění definovaných rozdělením rychlostí a maticí přechodu, která representuje výměnu vody mezi jednotlivými cestami. Predpokládá se exponenciální pokles nasycené hydraulické vodivosti s hloubkou [5].

Počáteční zásoba vody ve svahu a vstupy (déšt') během epizody jsou simulovány velkým množstvím diskrétních částic. V každém časovém kroku se částice pohybují v možných cestách proudění. Rychlost je částicím přisuzována náhodně z rozdělení rychlostí. Tímto způsobem Ize modelovat účinek preferenčního

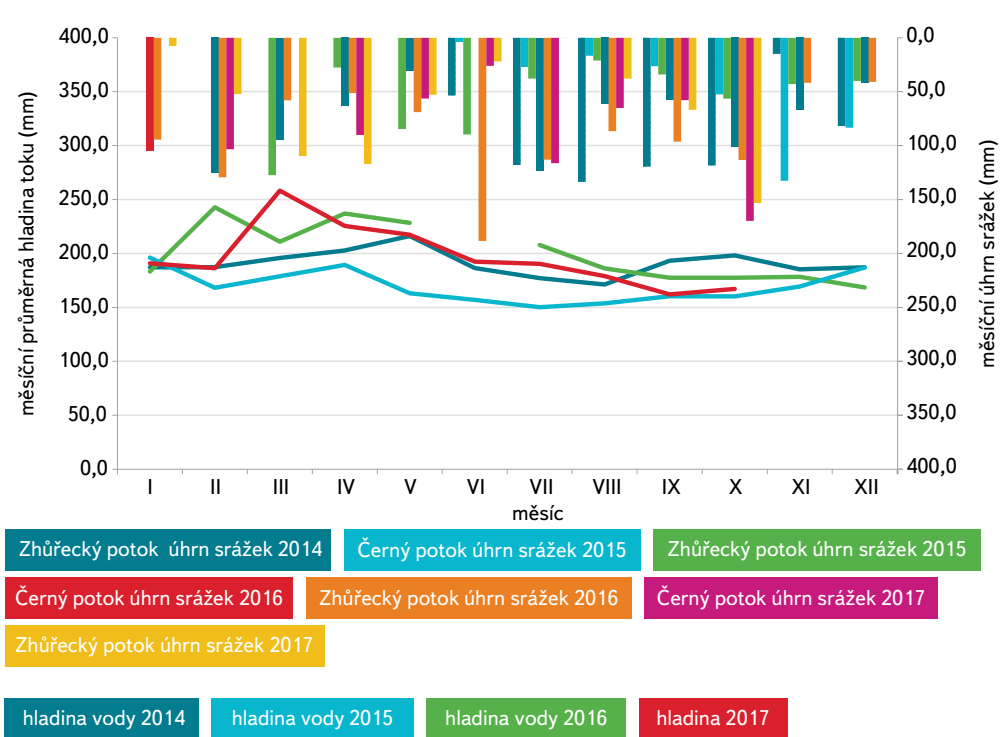

Obr. 2. Měsíční úhrny srážek a průměrné výšky hladiny vody ve stanicích PřF UK Černý potok a Zhůřecký potok na Šumavě 2014-2017

Fig. 2. Monthly precipitation totals and average water level depths in CUNI stations Černý potok and Zhůřecký potok at Šumava Mountains 2014-2017 (úhrn srážek - precipitation total; výška hladiny vody - water level depth; měsíční - monthly)

proudění a obchvatu (zkrácení) dráhy ve svahu bez explicitní znalosti geometrie cest proudění. Kontinuita je zajištěna bilancováním počtu částic [1, 5, 8].

K tomu, abychom mohli pracovat s modelem MIPs, potřebujeme tedy mít možné cesty odtoku prozkoumány s využitím stopovačů. Dále popisujeme pokusy, které jsme za tímto účelem provedli.

\section{Vybraná povodí}

Pro pokusy na experimentálním svahu byla vybrána dvě povodí.

1. Horní část povodí Lužické Nisy v Jizerských horách, konkrétně oblast $\vee$ Dolních Lučanech. Tok Lužická Nisa pramení v údolí rozkládajícím se na sever od Černostudničního hřebene v nadmořské výšce $639 \mathrm{~m} \mathrm{n}$. m. Ve vzdálenosti cca 2 km od pramene se nachází závěrový profil ČVUT - FSv Dolní Lučany, kde je sledována hladina a teplota vody, teplota a vlhkost vzduchu a úhrn srážek od roku 2013 (obr. 1). V roce 2014 jsme zde instalovali automatickou sněhoměrnou stanici LDSS [9]. Experimentální svah se nacházel cca $150 \mathrm{~m}$ proti proudu od závěrového profilu na pravé straně toku. Na podzim 2014 zde byly provedeny dva experimenty. V roce 2015 byl ve stejném povodí vybudován nový svah ve vzdálenosti asi 500 m od bývalého svahu, ve vzrostlém lese s převahou smrku ztepilého.

2. Povodí Černého potoka na Šumavě. Toto povodí patři celým územím do II. zóny ochrany a je hospodářsky využívané. Převážnou část tvoři les s převahou smrku ztepilého, doplněný porostem jedle bělokoré, buku lesního, javoru klenu a břízy bělokoré. Podrost je tvořen porostem borůvčí a travinou bikou lesní. Zamokřené plochy jsou porostlé rašeliníkem a sítinou rozkladitou.

V rámci diplomové práce [10] byly v povodí vyhloubeny půdní sondy za účelem odběrů půdních vzorků. Nejčastějším pưdním typem v povodí je kryptopodzol s různými podtypy, dále pak ranker, podzol nebo glej. Půdní typy jsou zde ovlivněny hlavně vegetací a sklonitostí. Sklonitost je v celém profilu víceméně podobná. Hloubky půdy se pohybují kolem 40-50 cm. Půdy mají velké množství skeletu. Srážky a hladiny v potocích jsou v obr. 2. 


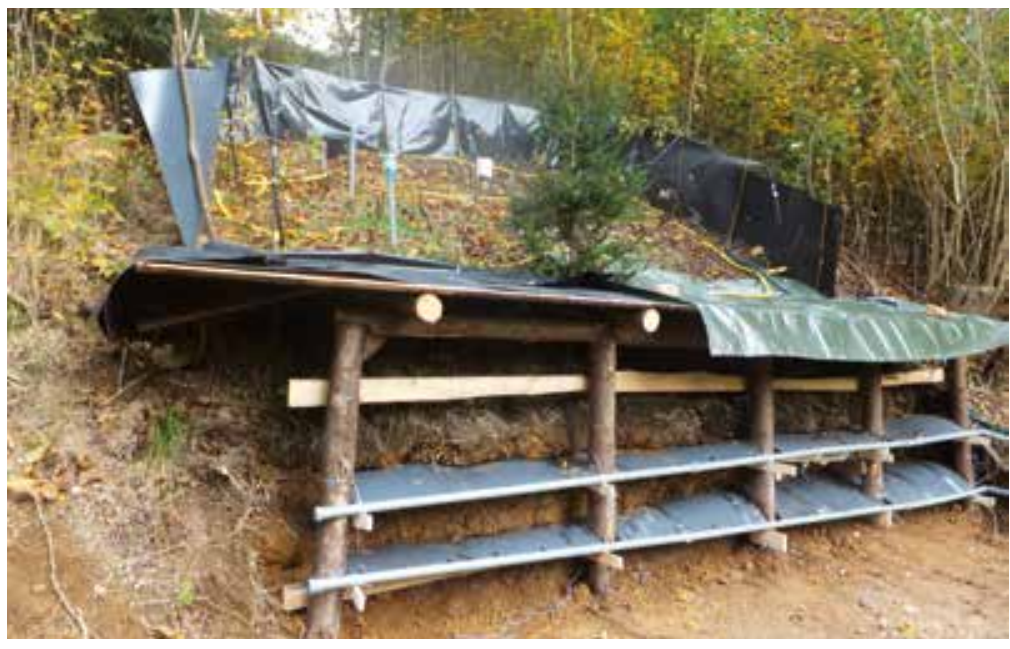

Obr. 3. Experiment na louce, Dolní Lučany, drážky 20 a $50 \mathrm{~cm}$ od povrchu Fig. 3. Experiment on the meadow, Dolní Lučany, troughs 20 and $50 \mathrm{~cm}$ from the surface

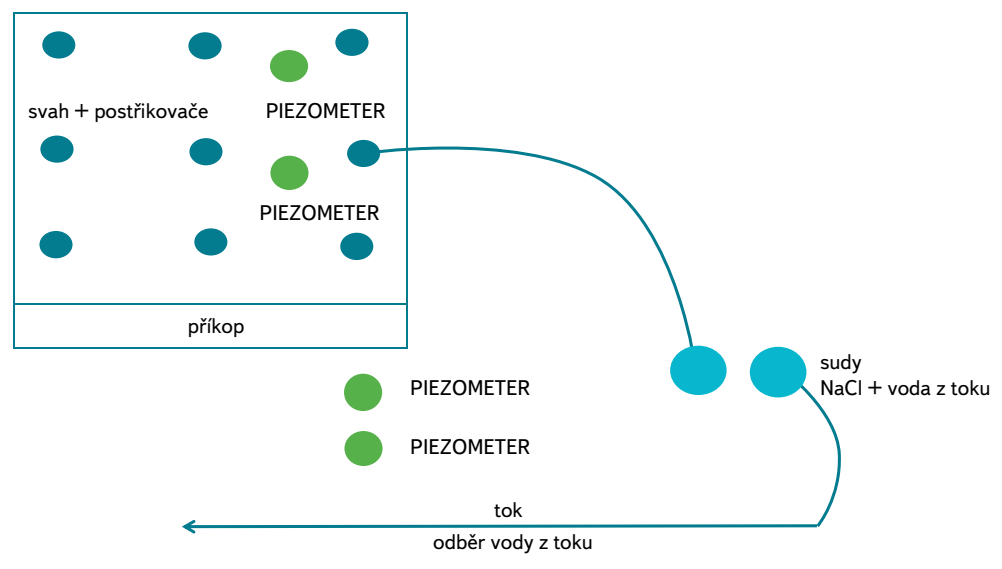

odběr na konci svahu

odběr vody $z$ toku před svahem

Obr. 4a. Schéma experimentu na louce v Dolních Lučanech - Jizerské hory Fig. 4a. Diagram of meadow experiment in Dolní Lučany - Jizera Mountains (svah slope, postřikovače - sprinklers, príkop - trench, tok - stream, sud - barrel, voda z toku - stream water, odběr vody z toku - stream water sampling sites, před svahem before slope, na konci svahu - at the end of slope)

\section{Schéma pokusů na louce a v lese pro potřeby modelu MIPs}

Celková plocha byla ohraničena vyšším plůtkem a na konci plochy se svah zaříz do hloubky 80-120 cm. V zářezu byly vyříznuty drážky dovnitř svahu hluboké cca 10 cm ve výškách 20 a 50 cm (obr. 3, 4a, 4b a 4c). Stékající voda z drážek byla odváděna okapem do velkých překlápěčů.

$\checkmark$ první fázi pokusu bylo obvykle skrápění prováděno čistou vodou z toku. Jako značkovač pro zjištění cest odtoku byla použita $\mathrm{NaCl}$, která se rozpouštěla v sudech

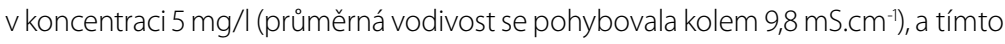
roztokem se skrápěla pokusná plocha.

Vodivost se měřla prístrojem firmy Hach s presností $\pm 0,5 \%$.

Předpokládalo se, že vzorky odtékající vody budou odebírány z překlápěčů ze sondy pod svahem a z blízkého toku: před pokusným svahem, ve středu pokusného svahu, z výtoku ze svahu (pokud byl rozeznatelný) a ve vybraném vzdálenějším místě. Ve vzorcích vody a v toku byla průběžně měřena elektrická vodivost. V laboratoři byla provedena analýza vzorků na množství $\mathrm{NaCl}$.

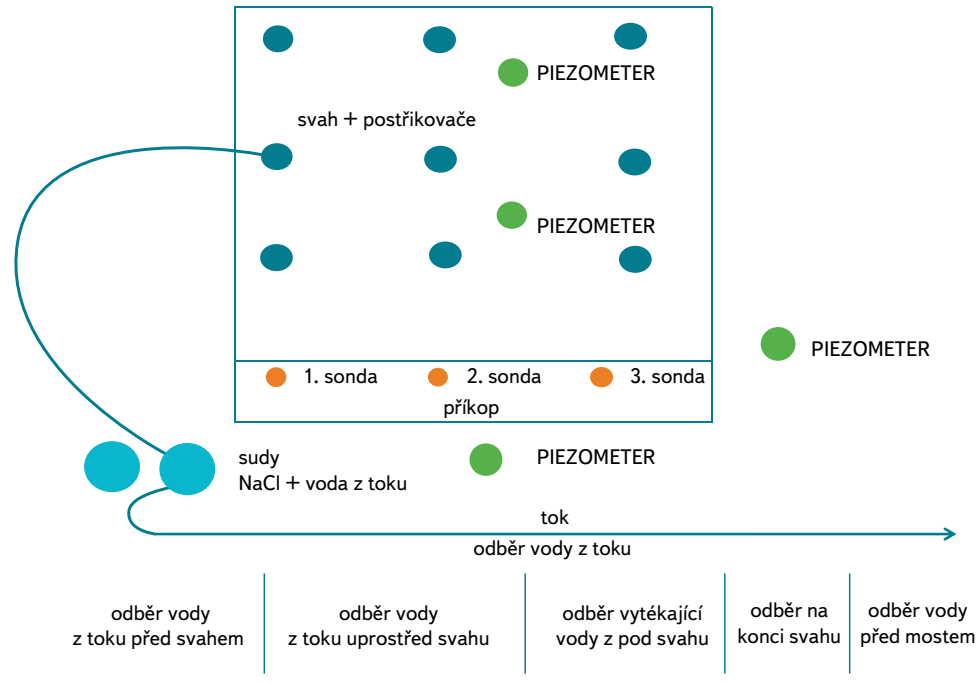

Obr. 4b. Schéma experimentu v lese v Dolních Lučanech - Jizerské hory

Fig. 4b. Diagram of forest experiment in Dolní Lučany - Jizera Mountains (svah - slope, postřikovače - sprinklers, príkop - trench, tok - stream, sonda - dug well, sud - barrel, voda z toku - stream water, odběr vody z toku - stream water sampling sites, pred svahem - before slope, uprostřed svahu - middle of slope, odběr vytékající vody z pod svahu - sampling water flowing into stream from the bank, i.e. a distinctly visible flow under stream water table, na konci svahu - at the end of slope, pred mostem - before bridge)

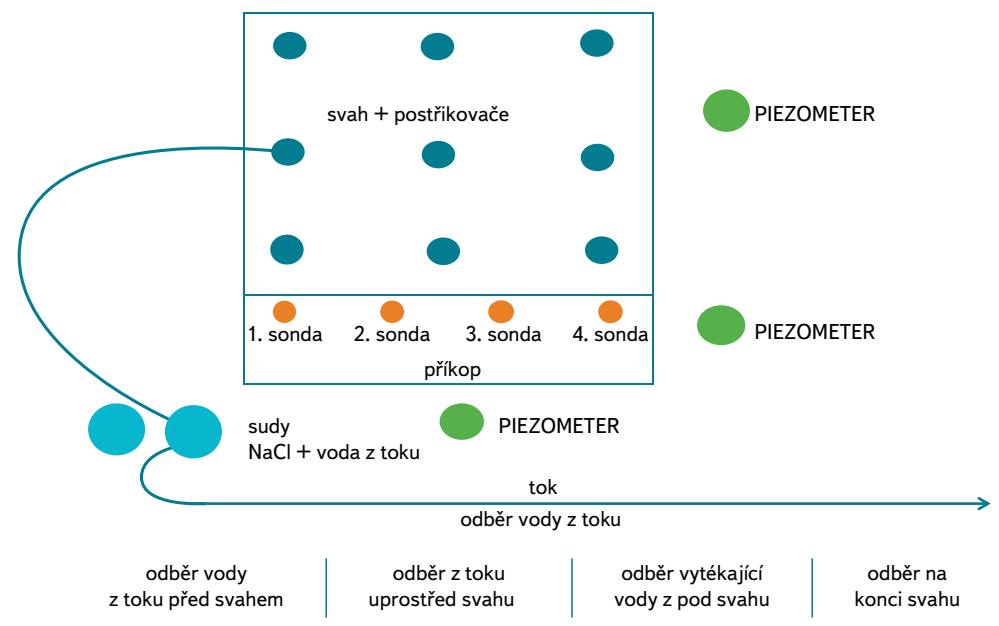

Obr. 4c. Schéma pokusu v lese v povodí Černého potoka

Fig. 4c. Diagram of forest experiment in Černý potok catchment - Šumava Mountains (svah - slope, postřikovače - sprinklers, príkop - trench, tok - stream, sonda - dug well, sud - barrel, voda z toku - stream water, odběr vody z toku - stream water sampling sites, před svahem - before slope, uprostřed svahu - middle of slope, odběr vytékající vody z pod svahu - sampling water flowing into stream from the bank, i.e. a distinctly visible flow under stream water table, na konci svahu - at the end of slope)

\section{Automatický rozstřikovací systém pro simulaci deště}

Na vytyčené ploše $25 \mathrm{~m}^{2}$ se instaluje do čtverce devět trysek postřikovače. Voda je přiváděna hadicí pomocí čerpadla z blízkého zdroje (toku, cisterny). Množství vody sledoval vodoměr s přesností $\pm 1 \mathrm{~cm}$. Připojený datalogger zaznamenával úhrn srážek ze srážkoměru s přesností $\pm 0,1 \mathrm{~mm}$ a vlhkost půdy z čidla Virrib $s$ přesností $< \pm 0,01 \mathrm{~m}^{3} \cdot \mathrm{m}^{-3}$. Toto čidlo bylo instalováno bud’ $v$ hloubce $25 \mathrm{~cm}$, nebo v hloubkách 20 a $50 \mathrm{~cm}$ [11]. 


\section{VÝSLEDKY EXPERIMENTU゚ PRO ZÍSKÁNÍ DAT DO MODELU MIPS}

\section{Experimenty $v$ lese}

\section{EXPERIMENTY V LETECH 2015 A 2016 \\ V LESE V DOLNIICH LUČANECH}

Na jaře 2015 byl vybudován experimentální svah ve vzrostlém lese s převahou smrku ztepilého. Svah se nalézal $1 \mathrm{~m}$ od toku. Pod svahem byl instalován piezometr na sledování hladiny podpovrchové vody [10]. Na této lokalitě bylo $\checkmark$ letech 2015 a 2016 provedeno celkem pět pokusů.

Rok 2015 (druhý rok delšího suchého období) byl sušši než rok predešlý. Sněhová pokrývka se vyskytovala přes celé zimní období, ale úhrn srážek od března do října činil jen 44,2 \% dlouhodobého úhrnu. Nejnižší hladiny v toku byly zejména $v$ letních měsících. Nedostatek vody významně ztěžoval práce na pokusu.

Pro instalování překlápěčů byly vyhloubeny jámy, které se po skrápění začaly plnit vodou. K protékání do žlabů bohužel nedošlo a jámy pod svahem byly použity jako sondy (obr. 4a, 4ba 4c). Současně byla měřena výška podpovrchové vody v piezometru pod svahem, která kolísala podle skrápění.

První pokus byl proveden od 12. 5. do 14. 5. 2015, kdy plocha byla nejdřive skrápěna čistou vodou, aby se zvětšila nasycenost půdního profilu. Poslední den byl aplikován postřik se solí. Souběžně byla měřena vodivost toku před pokusným svahem, v polovině svahu, na konci svahu a u mostku cca $5 \mathrm{~m}$ od svahu. Pod svahem vyvěrala za 2 dny voda, a tak byly vyvrtány další dvě sondy hluboké $40 \mathrm{~cm}$. Z těchto sond byly odebírány vzorky po dobu všech pokusů. Voda ze sond se inned ztrácela po skončení skrápění.

Další opakování pokusu 25. 6.-30. 6. 2015 bylo provedeno v době, kdy voda $\checkmark$ toku stoupla po predešlých srážkách. Z důvodu nedostatku vody se pokus opakoval v řijnu od 15. 10. do 19. 10. 2015. Průběh experimentu byl obdobný (obr. 5a, $5 b$ a $5 c)$.

Nejvyšší vodivosti byly dosahovány $v$ obou experimentech v sondě (jámě) pod svahem, ale oproti předešlému pokusu $\vee$ roce 2014 byly zaznamenány změny $v$ toku zejména $v$ místě u konce svahu, kdy ze břehu pod hladinou viditelně vytékala voda.

Rok 2016 byl bohatší na úhrn srážek zejména na sníh (57 \% dlouhodobého úhrnu). První experiment se konal v květnu 14.-21. 5. 2016. Svah byl skrápěn nejdřiv 3,5 dne pouze vodou a potom 3,5 dne s roztokem soli. Pravidelně byla měřena vodivost ve vybraných profilech $v$ toku. $\vee$ době skrápění roztokem soli byly odebírány i vzorky vody.

Půdní profil byl vyschlý a ani po skrápění nedošlo k odtoku vody do okapů, pouze voda začala vyvěrat v sondě pod svahem, ze které byly odebírány vzorky, a pravidelně byla měřena vodivost. Ve vzorcích bylo zjištěno velké množství soli a samozřejmě vodivost byla také vysoká.

Nejvyšší hodnoty vodivosti a nejvyšší hodnoty $\mathrm{NaCl}$ se vyskytovaly ve vzorcích odebíraných $v$ toku těsně $u$ břehu $v$ blízkosti experimentálního svahu (výtok), kdy viditelně odtékala voda pod hladinou z břehu do toku.

$\checkmark$ poslední den skrápění došlo k př́valovému dešti, který ovlivnil konec experimentu (snížla se vodivost toku, voda stékající po povrchu se dostala do sondy).

Obdobný průběh experimentu byl zaznamenán 17. 7.-24. 7. 2016.

\section{EXPERIMENT V POVODÍ ČERNÉHO POTOKA - ZÁŘÍ 2017}

Začátkem záři 2017 byl vybudován experimentální svah v horní části povodí Černého potoka na Šumavě (oblast Hưrka) ve vzrostlém lese (buk, smrk ztepilý, javor) v blízkosti turistické cesty na břehu potoka. Experiment začal 2. 9. 2017 a skončil 6. 9. 2017. Výška zářezu byla $120 \mathrm{~cm}$, drážky byly ve výšce $15 \mathrm{~cm}$ a $50 \mathrm{~cm}$ od rostlinného pokryvu (20 cm a $50 \mathrm{~cm}$ od povrchu). Vzdálenost svahu od toku

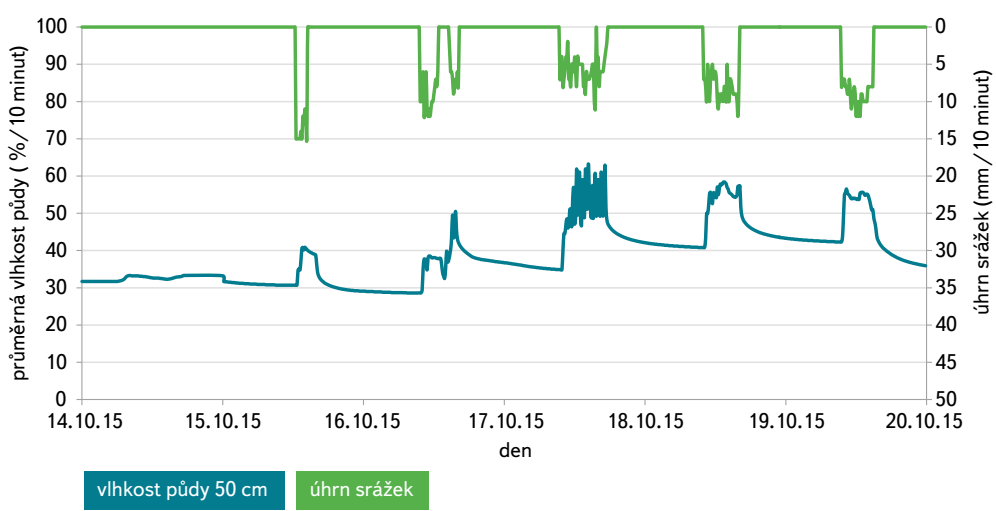

Obr. 5a. Povodí Nisy - les, Dolní Lučany - průběh skrápění a vlhkosti půdy 14. 10.-20. 10. 2015 Fig. 5a. Nisa catchment - forest, Dolní Lučany - sprinkling (mm per 10 minutes) and soil moisture (\% per 10 minutes) $14^{\text {th }}-20^{\text {th }}$ Oct. 2015

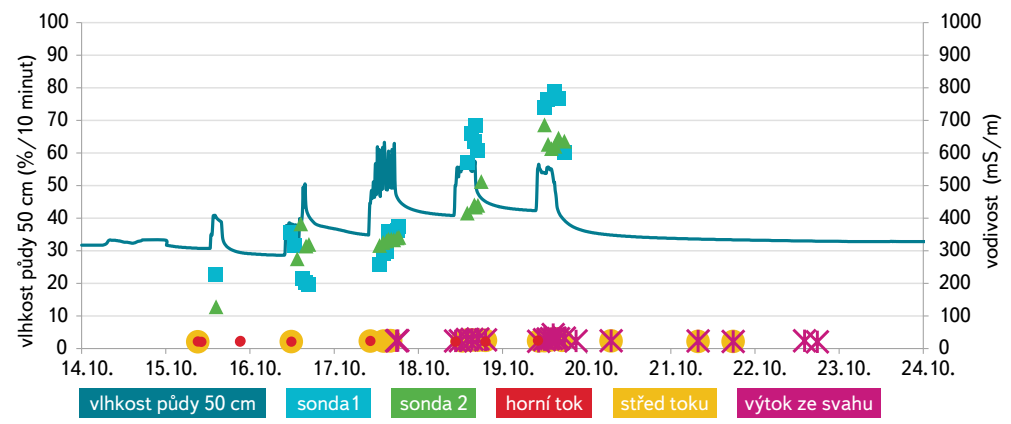

Obr. 5b. Jizerské hory - Dolní Lučany - les, průběh vodivosti v sondách a v toku a vlhkost půdy 14. 10.-24. 10. 2015

Fig. 5b. Jizera Mountains - Dolní Lučany - forest, conductivity $\left(\mathrm{mS}^{\mathrm{m}} \mathrm{m}^{-1}\right)$ and soil moisture at $50 \mathrm{~cm}$ (\% per 10 minutes) $14^{\text {th }}-24^{\text {th }}$ Oct. 2015 (sonda - dug well, horní tok upstream, střed toku - middle of stream, výtok ze svahu - flow from slope)

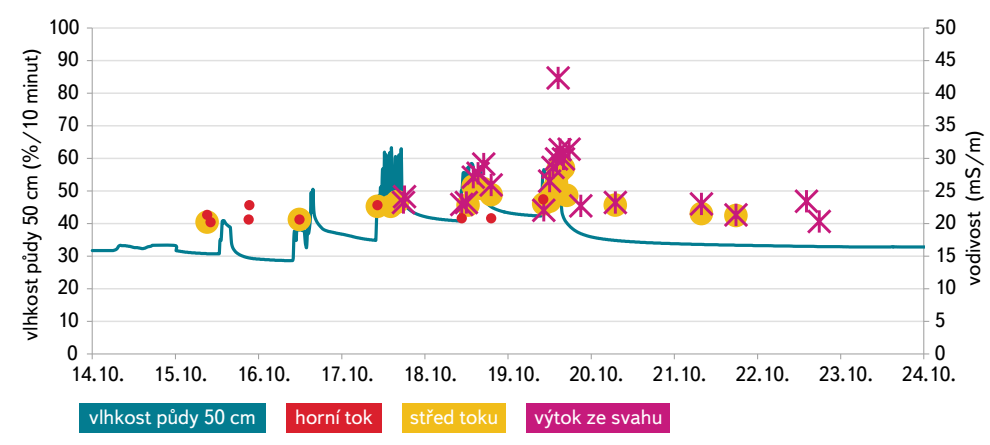

Obr. 5c. Jizerské hory - Dolní Lučany - les, průběh vodivosti v toku 14. 10.-23. 10. 2015 - detail Fig. 5c. Jizera Mountains - Dolní Lučany - forest, conductivity in stream 14 ${ }^{\text {th }}-23^{\text {rd }}$ Oct. 2015 detail (vlhkost půdy - soil moisture, horní tok - upstream, střed toku - middle of stream, výtok ze svahu - flow from slope)

činila cca 1,5 m. Vzorky z toku byly odebírány před experimentálním svahem, na jeho středu a za ním. Výtok ze svahu byl rovněž vzorkován. Schéma rozmístění postřikovačů, piezometrů a odběrných míst v toku a umístění sond je na obr. 4c.

Na obr. 2 jsou graficky znázorněny měsíční úhrny srážek a prưměrné měsíční výšky hladin z povodí Černého Potoka a Zhưřeckého Potoka ve stanicích PřF UK na Šumavě (2014-2017).

Pokus probíhal spíše za deštivého počasí. Druhý den experimentu se začala objevovat voda v sondách pod svahem. Další den prosakující voda v dolním 
levém rohu svahu vytékala jako povrchový odtok po kameni velkou rychlostí. Postupně vyvěrala voda i v dalších sondách. Ani v tomto případě však netekla z drážek do překlápěčů. Průběh pokusu je graficky znázorněn na obr. $6 a, 6 b$ a $6 c$.

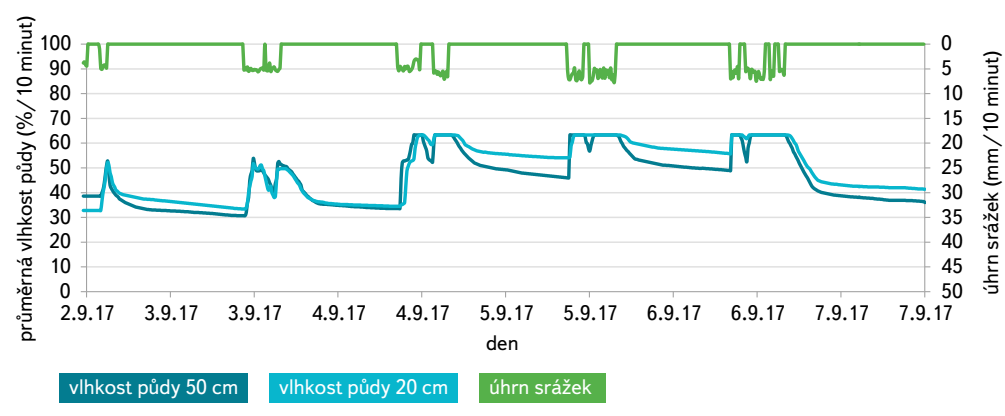

Obr. 6a. Povodí Černého Potoka - les, průběh skrápění a vlhkosti půdy 2. 9.-7. 9. 2017 Fig. 6a. Černý potok catchment - forest, sprinkling (mm per 10 minutes) and soil moisture (\% per 10 minutes) $2^{\text {nd }}-7^{\text {th }}$ Sept. 2017

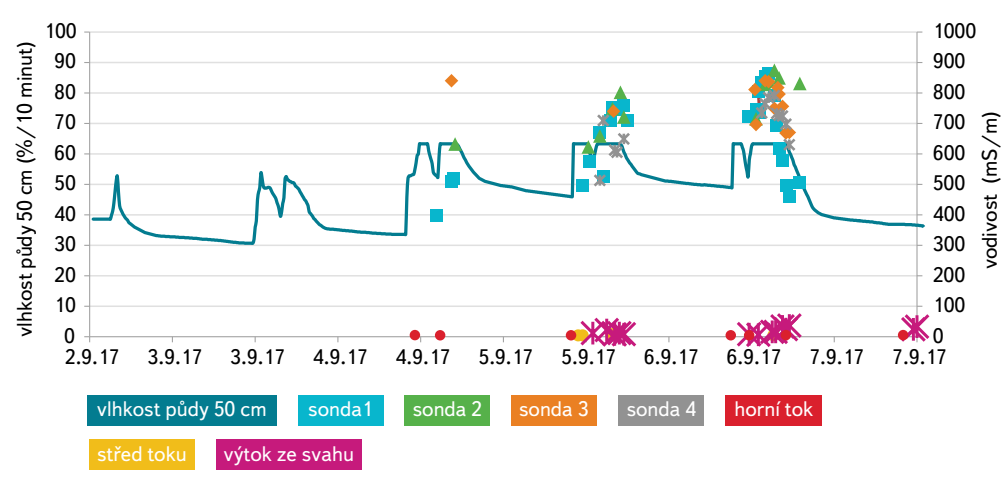

Obr. 6b. Šumava - Povodí Černého Potoka - les, průběh vodivosti v sondách a v toku 2. 9.-7. 9. 2017

Fig. 6b. Šumava Mountains - Černý potok catchment - forest, conductivity in dug wells and in stream $2^{\text {nd }}-7^{\text {th }}$ Sept. 2017 (vlhkost půdy - soil moisture, sonda - dug well, horní tok - upstream, střed toku - middle of stream, výtok ze svahu - flow from slope)

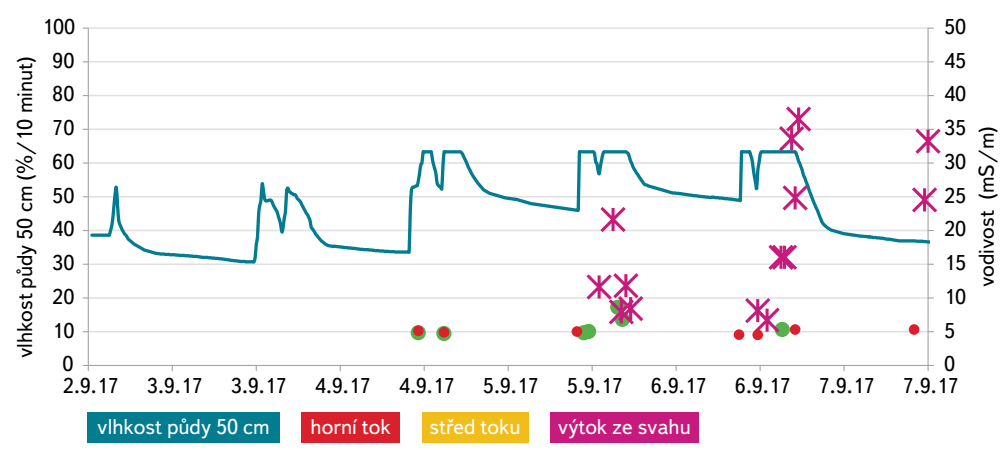

Obr. 6c. Šumava - Povodí Černého Potoka - les, průběh vodivosti v toku 2. 9.-7. 9. 2017 - detail

Fig. 6c. Šumava Mountains - Černý potok catchment - forest, conductivity in stream $2^{\text {nd }} 7^{\text {th }}$ Sept. 2017 - detail (vlhkost půdy - soil moisture, horní tok - upstream, střed toku - middle of stream, výtok ze svahu - flow from slope)

\section{Experimenty na louce -2014}

Rok 2014 patřil mezi velmi suchá období (69 \% dlouhodobého průměru za období III-X). Nedostatek srážek v zimě, v létě i na podzim se projevil nízkou hladinou v toku. Průměrné nejnižší hladiny toku byly dosaženy v srpnu a v podzimních měsících (obr. 1).

Experimentální svah byl instalován cca $5 \mathrm{~m}$ od toku. Byly provedeny dva pokusy: 7. 10.-9. 10. 2014 a 20. 10.-21. 10. 2014.

Období první třetiny října bylo velmi suché (48 \% dlouhodobého průměru). Hladina toku byla velmi nízká a vlhkost půdy v hloubce $50 \mathrm{~cm}$ činila $21 \%$ objemové půdní vlhkosti. K odtékání z půdního profilu do žlabů docházelo až třetí den (9. 10.). Při druhém pokusu za 14 dnů do vlhčí půdy (asi 30 \%) odtok nastal hned první den. Součástí pokusu bylo sledování hladiny podpovrchové vody $\checkmark$ piezometrech pod svahem. Současně se odebíraly vzorky povrchové vody z toku před pokusným svahem a za svahem. Schéma svahu s odběrnými místy je znázorněno na obr. $4 a$.

Na obr. 1 jsou graficky znázorněny měsiční úhrny srážek a průměrné měsíční výšky hladiny naměřené ve stanici ČVUT $\vee$ Dolních Lučanech $\vee$ Jizerských horách (2014-2016).

\section{POKUS 7. 10. DO 9.10. 2014}

Svah se skrápěl tři dny pouze roztokem $\mathrm{NaCl}$. Voda ze svahu začala protékat až třetí den skrápění, tj. 9. 10. 2014, a to nejprve ze spodního žlabu (9. 10. od 10:50) a později i z horního od 11:50 (obr. 7a).

Nejvíce vody odteklo z dolního žlabu a současně zde byla naměřena nejvyšší vodivost 9. 10. 2014 ve 14:30 $807 \mu$ S.cm-1.

\section{POKUS 20.10. DO 21. 10. 2014}

První den byl svah skrápěn pouze vodou a druhý den skrápění pokračovalo s roztokem soli. Kodtékání ze svahu došlo již na začátku prvního dne z dolního okapu - voda odtékala do spodního překlápěče. V poledne začala voda odtékat i z horního okapu do horního překlápěče. Druhý den pokračovalo skrápění roztokem $\mathrm{NaCl}+\mathrm{H}_{2} \mathrm{O}\left(5 \mathrm{mg} . \mathrm{I}^{-1}\right)$ a od začátku skrápění voda odtékala do obou překlápěčů. Dne 21. 10. byla naměřena nejvyšší hodnota vodivosti ve 12:15 v dolním žlabu (okapu) $8270 \mu$ S.cm-1. V horním žlabu byly nejvyšší vodivosti dosahovány ve vzorcích odebraných 20. 10. 2014 16:00 hod. $8700 \mu$ S.cm-1.

Současně byla měřena vodivost i v toku, ale vzhledem k vzdálenosti pokusného svahu od toku se vodivost téměř neměnila. Hodnoty $\mathrm{NaCl}$ byly změřeny jen u několika vzorků, a proto je neuvádíme. Nebyla naměřena žádná změna hladiny podpovrchové vody $v$ instalovaných piezometrech (hloubka v blízkosti svahu byla $50 \mathrm{~cm}$, v blízkosti vody $40 \mathrm{~cm}$ ).

\section{SCÉNÁŘ VSAKOVÁNÍ VYDATNÉ SRÁŽKY DO SUCHÉ PŮDY}

Na obr. 7a a 7b je príklad výstupu modelu MIPs, který ukazuje sycení experimentálního svahu umělým deštěm.

Experimentální svah má plochu $5 \times 5 \mathrm{~m}$. Ve vstupech do modelu je délka svahu $5 \mathrm{~m}$ rozdělena na oddíly po 0,5 m, tzn. že svah má 10 oddílü, které vidíme na vodorovné ose na obr. 7b. Na svislé ose je vykresleno množství částic $v$ př́slušném časovém kroku a v príslušném oddílu. Jedna „částice“ má ve výpočtu objem 1 litr. Časový krok výpočtu je stejný jako časový krok měření, tj. 10 minut.

V horních obrázcích je vykreslena nenasycená (proměnlivě nasycená) zóna, ve spodních nasycená zóna (mělká podzemní voda). Označení A, B, C odpovídá označení na obr.7a, tedy jsou to počty částic $v$ době, kdy skončil postřik. 
Modelem je možno vyjádřit scénáře zvětšení klimatických extrémů - velmi vydatná srážka do suché půdy - a ověřovat hypotézy podle experimentů v terénu. $V$ našem případě jsme tedy modelovali srážky o velikosti 185,5, 223 a 231,6 mm (je možno srovnat s maximálním denním úhrnem 345 mm v ČR, naměřeným na Nové Louce $v$ Jizerských horách).

Při modelování odtoků ze srážek je první vlna po suchém období zpravidla zatížena velkou chybou ( $v$ desítkách procent), což je způsobeno velkou nelinearitou proměnlivě nasycené půdní zóny. Bylo tomu tak i predtím, než se začal projevovat vliv klimatické změny. Scénáře vsakování vydatných srážek do suché půdy a tvorba povodňového odtoku modelem MIPs, založeném na jiném aparátu než Richardsova rovnice [14], může tedy přispět k rozboru problému tvorby odtoku v podmínkách klimatické změny.

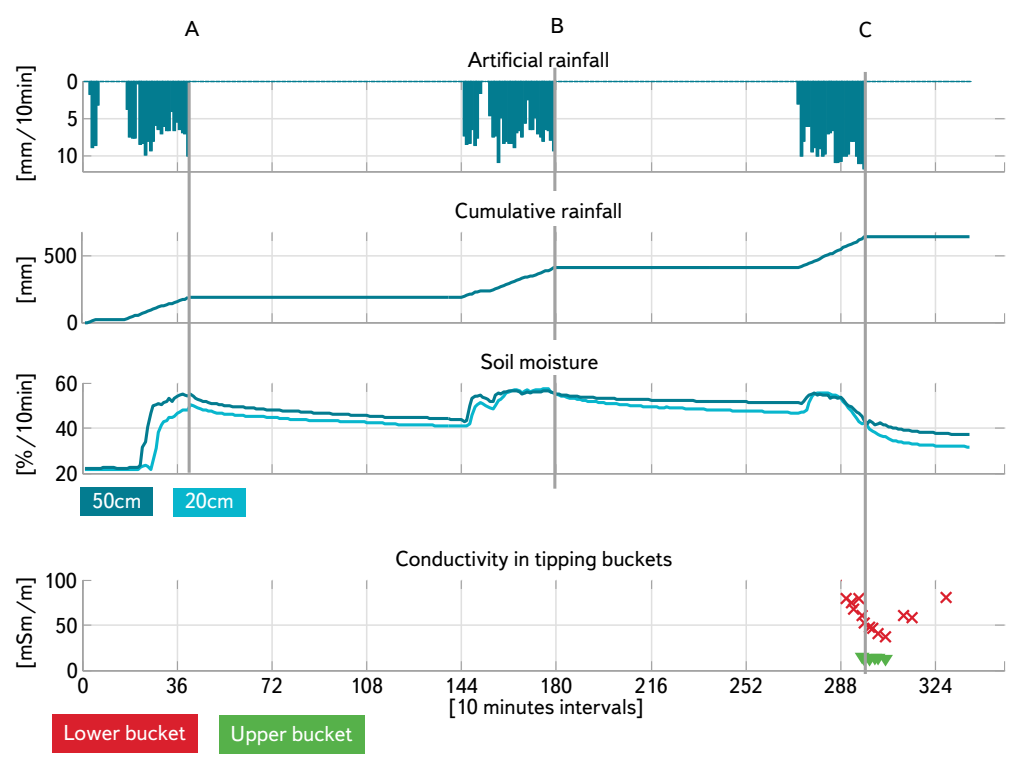

Obr. 7a. Dolní Lučany, louka: umělý déšt', kumulativní déšt, vlhkost ve 20 a 50 cm, vodivost v preklápěčích, A, B, C časové okamžiky ukončení deště Fig. 7a. Dolní Lučany, meadow: artificial rain, cumulative rain, conductivity in tipping buckets, $A, B, C$ times of rainfall end
A

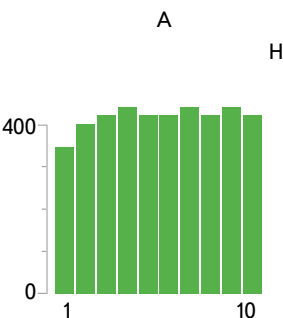

B

istogram of particles in the unsaturated zone

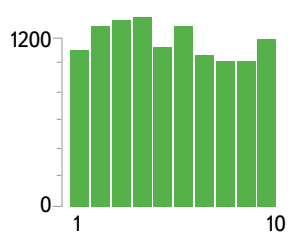

C

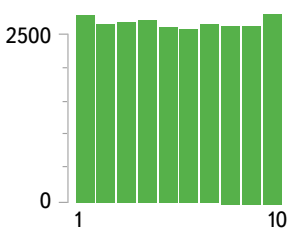

Histogram of particles in the saturated zone
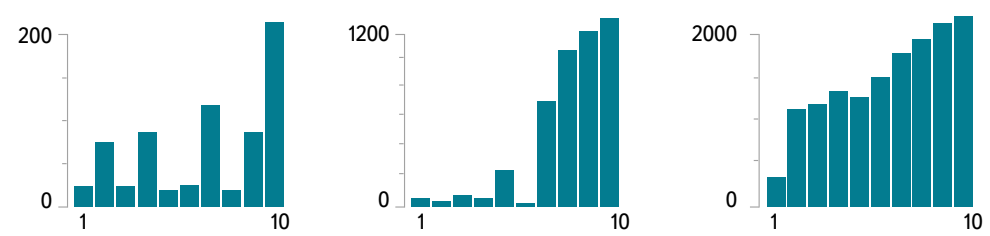

Obr. 7b. Histogramy počtu částic v časech A, B a C (viz obr. 7a), horní obrázky (zeleně) nenasycená zóna, dolní obrázky (modře) - nasycená zóna, na vodorovné ose délka svahu dělená po $0,5 \mathrm{~m}$

Fig. 7b. Histograms of numbers of particles at times A, B and C (fig. 7a), horizontal axis is subdivided by $0.5 \mathrm{~m}$

\section{ZHODNOCENÍ A ZÁVĚRY}

Tabulka 1 uvádí období skrápění, spotřebu čisté vody, spotřebu roztoku vody a $\mathrm{NaCl}$ (koncentrace $v$ průměru $5 \mathrm{~g} . \mathrm{I}^{-1}$, tj. průměrný úhrn v mm). Tabulka 2 uvádí maximální hodnoty vodivosti a koncentrace $v$ odebraných vzorcích $u$ všech experimentů.

Z uvedených dosažených výsledkư vyplývají následující závěry.

\section{VIhkost půdy a odtok vody}

Vlhkost půdy ve všech experimentech se zvyšovala v závislosti na délce skrápění.

Nejdelší skrápění bylo provedeno při experimentech $v$ roce 2016, kdy se nejdéle skrápělo čistou vodou $v$ období 18. 7.-23. 7. $20: 36$ hodin a v období 14. 5.-20. 5. nejvíce roztokem $\mathrm{NaCl}$ (21:28 hod), viz tabulka 1.

Při kratších skrápěních (Dolní Lučany na louce) maximální vlhkost půdy dosahovala $56,5 \%$, ale při delších obdobích skrápění byly od 3.-5. dne stabilně maxima 63,3\%, např. obr. $6 a$.

Při prvním experimentu na louce začal odtok vody do překlápěčů až třetí den (9. 10.), ale při opakování (20. 10.-21. 10.) již první den voda protékala oběma překlápěči. Na skrápěné ploše docházelo, na málo propustném povrchu, také k povrchovému odtoku.

Při lesních experimentech, i přes delší období skrápění, voda do překlápěčů neodtékala, ale vyvěrala těsně pod zářezem svahu. Pro sledování vodivosti a koncentrace $\mathrm{NaCl}$ byly $\vee$ těchto místech vyhloubeny sondy cca $30-40 \mathrm{~cm}$ hluboké, viz obr. 4b. K povrchovému odtoku v lese ani přes velké úhrny srážek nedocházelo. Zřejmě je důvodem větší prítomnost preferenčních cest (makropóry, dutiny po kořenech a žížalách apod.) a tedy větší propustnost půdy.

\section{Konduktivita vody}

$\checkmark$ době experimentu byly několikrát za den odebírány vzorky z toku před pokusným svahem. Na Lužické Nise v Dolních Lučanech se vodivost pohybovala od 14,5 do 18,6 mS.m $\mathrm{m}^{-1}$ a na Šumavě byla kolem 5 mS. $\mathrm{m}^{-1}$.

Při prvním ani druhém experimentu na louce $v$ Dolních Lučanech se neprokázal žádný vliv na vodivost v toku. Svah byl ve větší vzdálenosti od toku a byl zde vykopán príkop pro plynové potrubí, který narušil přirozený terén. Z tohoto důvodu byly dalši experimenty přeneseny do blízkého lesa.

$\checkmark$ lese při skrápění docházelo k zřetelnému výtoku ze břehu pod hladinou do koryta $v$ blízkosti svahu. Vodivost $v$ tomto místě začala stoupat 3.-4. den skrápění. Příklad průběhu vodivosti v toku je vykreslen na obr. 5c. Nejvíce se projevil odtok ze svahu do toku v posledním roce pokusu v povodí Černého potoka na Šumavě, viz obr. 6c a tabulka 2.

Vodivost v odebraných vzorcích z překlápěčů a ze sond postupně stoupala a největší byla v posledním dni skrápění roztokem $\mathrm{NaCl}$. Nejvyšší maximální hodnota byla naměřena v posledním pokusu na Šumavě.

Odtok vody ze svahu závisí především na preferenčních cestách, kdy v lesním porostu je velké množství cest po kořenech a makropórů. Voda prosakuje spíše do spodních vrstev pưdního profilu a stéká po málo propustném podloží laterálně do toku. Objevuje se u paty svahu v sondách a ve výtoku (pod hladinou) ze břehu do koryta. Na louce se laterální pohyb odehrával v menší hloubce, popř. po povrchu po nepropustných plochách. Podstatný je též sklon terénu a nepropustné nebo málo propustné podloží. 
Tabulka 1. Lokality, obdobi skrápěni, spotřeba čisté vody, spotřeba roztoku vody a NaCl (v prưměru $5 \mathrm{~g} / 1)$, prüměrný hodinový úhrn v mm Table 1. Sites, sprinkling period, volume clean water used (litres), volume NaCl solution (about $5 \mathrm{~g} / \mathrm{ll}$, average rain total ( $\mathrm{mm}$ per hour)

\begin{tabular}{|c|c|c|c|c|c|c|c|}
\hline \multirow[t]{2}{*}{ Lokality } & \multirow[t]{2}{*}{ Období } & \multicolumn{2}{|c|}{ Objem použité vody [I] } & \multicolumn{2}{|c|}{ Doba skrápění [hod.] } & \multicolumn{2}{|c|}{ Celkový úhrn $[\mathrm{mm} / \mathrm{hod}]}$. \\
\hline & & $\mathrm{H}_{2} \mathrm{O}$ & $\mathrm{H}_{2} \mathrm{O}+\mathrm{NaCl}$ & $\mathrm{H}_{2} \mathrm{O}$ & $\mathrm{H}_{2} \mathrm{O}+\mathrm{NaCl}$ & $\mathrm{H}_{2} \mathrm{O}$ & $\mathrm{H}_{2} \mathrm{O}+\mathrm{NaCl}$ \\
\hline \multicolumn{8}{|c|}{ Jizerské hory - Dolní Lučany } \\
\hline \multirow[t]{2}{*}{ louka 2014} & 7.-9. ř́jen 2014 & 4359 & 10401 & 03:13 & $12: 10$ & 54,3 & 34,3 \\
\hline & 20.-21. řijen 2014 & 6948 & 6817 & 05:52 & 06:31 & 50,3 & 43,2 \\
\hline \multirow[t]{2}{*}{ les 2015} & 25.-30. červen 2015 & 7642 & 18133 & 09:10 & $20: 10$ & 33,6 & 36,1 \\
\hline & 15.-19. říjen 2015 & 10883 & 23069 & $11: 20$ & $18: 47$ & 40,1 & 49,2 \\
\hline \multirow[t]{2}{*}{ les 2016} & 14.-20. květen 2016 & 17810 & 28488 & $09: 26$ & $21: 28$ & 76,9 & 53,5 \\
\hline & 18.-23. červenec 2016 & 25232 & 18100 & $20: 36$ & 19:09 & 49,6 & 36,4 \\
\hline \multicolumn{8}{|c|}{ Šumava - Černý potok } \\
\hline les 2017 & 2.-6. září 2017 & 8505 & 19991 & 09:54 & $11: 37$ & 35,66 & 48,9 \\
\hline
\end{tabular}

Tabulka 2. Dosažené maximální hodnoty vodivosti v prekklápěčích, sondách, v toku a ve výtoku při experimentech 2014-2017

Table 2. Maximum conductivity in tipping bucketes, dug wells, in stream and in outflow from slope during experiments 2014-2017

Lokality

Období

Konduktivita $\left[\mathrm{mS} . \mathrm{m}^{-1}\right]$

\begin{tabular}{|c|c|c|c|c|c|}
\hline & & překlápěče & sondy & tok & odtok ze svahu \\
\hline \multicolumn{6}{|c|}{ Jizerské hory - Dolní Lučany } \\
\hline \multirow[t]{2}{*}{ louka 2014} & 7.-9. ř́jen 2014 & 60,4 (9. ř́jen 11:50) & & 14,8 & žádný odtok \\
\hline & 20.-21. řijen 2014 & 870 (21. říjen 12:15) & & 15,5 & žádný odtok \\
\hline \multirow[t]{2}{*}{ les 2015} & 25.-30. červen 2015 & & 798 (30. červen 18:00) & 17,0 & 18,8 (29. červen 12:20) \\
\hline & 15.-19. ř́ijen 2015 & & 788 (19. ř́ijen 15:00) & 23,7 (19. říjen 10:10) & 42,3 (19. ř́ijen 14:30) \\
\hline \multirow[t]{2}{*}{ les 2016} & 14.-20. květen 2016 & & 774 (20. květen 10:30) & 17,2 (19. květen 10:40) & 21,4 (17. květen 16:00) \\
\hline & 18.-23. červenec 2016 & & 773 (23. červenec 14:09) & 18,6 (20. červenec 14:50) & 32,7 (23. červenec 16:09) \\
\hline \multicolumn{6}{|c|}{ Šumava - Černý potok } \\
\hline les 2017 & 2.-6. září 2017 & & 862 (6. září 14:30) & 36,5 (6. zárí 17:30) & 36,5 (6. září 17:30) \\
\hline
\end{tabular}




\section{Modelování}

Model MIPs [2,5] je založen na metodě sledování dráhy částic. Nepracuje s Richardsovou rovnicí [14] pro nenasycenou půdní zónu a je tedy alternativou k modelům duální pórovitosti [15]. Právě nenasycená zóna svojí nelinearitou zpưsobuje největší potíže při modelování odtoku. První povodňová epizoda po suchém období (i po běžném sezonním suchu) bývá obvykle špatně vystižena.

MIPs je vhodným nástrojem ke zkoumání v tomto směru. K tomu přispívá i vizualizace procesů - je možno sledovat pohyb jednotlivých částic (rozumí se balíčků vody o objemu např. 1 litr) mezi povrchovým a podpovrchovým odtokem, mezi nasycenou a nenasycenou zónou apod. To ovšem neznamená, že nejistoty spojené s proměnlivě nasycenou půdní zónou zmizí. Výpočty MIPs bude vhodné provádět $v$ rámci odhadu nejistot. Model MIPs je výpočetně náročný a vyhodnocení nejistot tuto náročnost ještě znásobí. Model duální pórovitosti je ovšem náročný také. To plyne z velké variability prírodních podmínek, zejména proměnlivě nasycené půdní zóny.

MIPs bude vhodný i ke zkoumání pohybu znečištění v půdním prostředí (pokud je založen na datech z průzkumu se stopovači). V podmínkách klimatické změny se zřejmě zvětšuje extremita povodní a sucha. Lze se tedy obávat přivalových srážek do půdy vyschlé dlouhotrvajícím suchem.

\section{Poděkování}

Přispěvek byl zpracován v projektu GA ČR 13-32133S. Druhá autorka děkuje prof. Bevenovi za poskytnutí programu MIPs. Dále děkujeme ČHMÚ a FSV ČVUT za poskytnutí dat a anonymním oponentům za cenné pripomínky.

\section{Literatura}

[1] BEVEN, K., HORNBERGER, G.M., and GERMANN, P. Hillslope hydrology, a multiple interacting pathways model. Paper presented at Second National Hydrology Symposium, 1989. British Hydrological Society, Sheffield, U. K.

[2] DUNNE, T. Field studies of hillslope flow processes. In: Kirkby, M.J., ed. Hillslope Hydrology, New York: Wiley, 1978, p. 227-293. ISBN 047199510X.

[3] DAVIES, J., BEVEN, K.J., NYBERG, L., and RODHE, A. A discrete particle representation of hillslope hydrology: hypothesis testing in reproducing a tracer experiment at Gardsjön, Sweden. Hydrological Processes, 2011, 25, p. 3602-3612. DOl:10.1002/hyp.8085

[4] CÍSLEROVÁ, M. a VOTRUBOVÁ, J. CT derived porosity distribution and flow domains. Journal of Hydrology, vol. 267, No. 3-4, October 2002, p. 186-200.

[5] BEVEN, K.J. and GERMANN, P.F. Water flow in soil macropores II. A combined flow model. European Journal of Soil Science, 1981, 32(1), p. 15-29.

[6] BEVEN, K.J. and GERMANN, P.F. Macropores and water flow in soils. Water Resources Research, 1982, 18(5), p. 1311-1325.

[7] BEVEN, K.J. and GERMANN, P.F. Macropores and water flow in soils revisited. Water Resources Research, 2013, 49(6), p. 3071-3092. DOI:10.1002/ wrcr.20156.

[8] BEVEN, K.J. MIPs model., R-code, Lancaster University.

[9] KULASOVÁ, A. a kol. Vývoj př́stroje a metodiky na kontinuální stanovení vodní hodnoty sněhu $v$ terénu. Projekt TAČR TA01020673, 2014

[10] VLČEK, L. Retence vody půdou $v$ experimentálních povodích se zaměřením na organozemě. Diplomová práce, 2011.

[11] BAGAL, Z. In: Blažková, Š. a kol. Kritické zdrojové oblasti fosforu v povodí jako rozhodujicí faktory transportu - pokus o vyjádřenív závislosti na zdrojových oblastech odtoku a zpưsobu hospodařeni. Projekt MŠMT LH12017, 2012.

[12] HORNBERGER, G.M., GERMANN, P.F., and BEVEN, K.J. Throughfall and solute transport in an isolated sloping soil block in a forested catchment. Journal of Hydrology, 1991, 124, p. 81-99.

[13] KULASOVÁ, A. a BLAŽKOVÁ, Š.D. Vliv extrémního deště na odtok z experimentálního svahu. Konference Hydrologie malého povodí, 2017.

[14] RICHARDS, L.A. Capillary conduction of liquids through porous mediums. Physics, 1931, 1, p. 318-333. [15] VOGEL, T, GERKE, H.H. ZHANG, R, and VAN GENUCHTEN, M.T Modeling flow and transport in a two-dimensional dual-permeability system with spatially variable hydraulic properties. Journal of Hydrology, vol. 238, No. 1-2, November 2000, p. 78-89.

\section{Autoři}

Ing. Alena Kulasová

凶alenakulas@email.cz

Ing. Šárka Blažková, DrSc.

凶sarka.blazkova@vuv.cz

RNDr. Lukáš Vlček, Ph.D. ${ }^{2}$

凶lukas.vlcek@natur.cuni.cz

prof. RNDr. Bohumír Janský, CSc. ${ }^{2}$

凶bohumir.jansky@natur.cuni.cz

'Výzkumný ústav vodohospodářský T. G. Masaryka, v. v. i.

${ }^{2}$ Prírodovědecká fakulta Univerzity Karlovy

Přispěvek prošel lektorským řízením.

\section{RUNOFF GENERATION MONITORING ON THE HILLSLOPES OF JIZERA AND ŠUMAVA MOUNTAINS USING TRAC- ING EXPERIMENTS FOR MIPS MODEL}

\section{KULASOVA, A.'; BLAZKOVA, S.'; VLCEK, L. ${ }^{2}$; JANSKY, B. ${ }^{2}$}

'TGM Water Research Institute, p.r.i.

${ }^{2}$ Faculty of Science, Charles University

Keywords: MIPs - hillslope model - tracing experiments run-off processes - particle tracking

The contribution presents experiments with artificial rainfall and a tracer in the Jizera Mountains which are indispensable for hillslope modelling with MIPs (Multiple Interacting Pathways [1]). Experiments on 2 hillslopes in the Lužická Nisa catchment in the Jizera Mountains and on one hillslope in the Šumava Mountains are described in detail. MIPs is based on the particle tracking technique and distribution of probabilities. It works with particles (packages of water) in different pathways defined by velocity distribution and transition matrix which represent exchange of water between individual pathways. Output of the MIPs model was shown for experimental slope on the meadow as a computation of the scenario of gradual saturation of slope during rain events, in particular of the first event after a dry period. The results from the field experiments show the difference between the runoff from meadow and forest slopes. In spite of using high intensities and large volumes of water on forest slopes the high infiltration capacities played the decisive role in the forest. The important effect of preferential pathways is probably the main reason. 